\title{
Developing A Mini Research Guide Book On Student Development Subject
}

\author{
Rahmulyani $^{1^{*}}$, Nasrun $^{2}$, Nani Barorah ${ }^{3}$, Nindya Ayu Pristanti ${ }^{4}$ \\ 1,2,3,4Universitas Negeri Medan, Indonesia \\ rahmulyani@yahoo.co.id
}

\begin{abstract}
This study aims to develop a mini research guidebook on student development subject for first semester education students in Universitas Negeri Medan. This research is a development study following the Borg and Gall model. The subjects were the first semester education's students in Universitas Negeri Medan. Expert's judgment includes content expert and instructional media expert. The method of taking the subject used purposive sampling. The data collection method used a questionnaire. The main field trial used 50 students and the operational field trial used 150 students. The results of the research development is based on the assessment of material experts obtained 97.5 with a very good category, media experts obtained 93 as an excellent category. The main field trial is 95.18 as very good category and the operational field trial is 91.78 as very good criteria. It can be concluded that a mini research guidebook on student development subject is appropriate to be used as a learning media.
\end{abstract}

Keywords: Guide Book, Mini Research, Student Development.

\section{Introduction}

Student Development Course is a basic education subject with a load of two credits and is given in semester I. This course is a University course, so that all educational students in Unimed are required to take this course in semester I. The purpose of this course is to equip students in forming and developing basic professional skills in education in an effort to understand the development of students. Through this course, students are expected to be able to understand each student's development in adolescence which consists of physical, cognitive, language, emotional, social, special talents, morals, developmental tasks, self-concept, selfadjustment and personality.

The results of observations and interviews with a number of lecturers who have taken courses in Student Development at Medan State University stated that there is a need for a guidebook to help students carry out mini research assignments. Supporting lecturers generally do not provide a guidebook to give to students so that students can practice independently. If this system continues to be conducted, the competencies and skills of students in conducting mini research cannot be honed in depth because it is not yet clear the direction of mini research conducted by lecturers and students without a guidebook.

Student competencies in conducting mini research can be trained independently with practice outside of class hours to answer the challenges of the Indonesian National Qualifications Framework Curriculum where S-1 graduates have reached level 6 which means they are able to apply their fields of expertise and utilize science, technology, and / or art in 
their fields in problem solving and being able to adapt to the situation at hand, mastering the theoretical concepts of a particular field of knowledge in general and the theoretical concepts of special sections in that field of knowledge in depth [1]. The Indonesian National Qualifications Framework Curriculum is embodied in a number of assessments, one of which is the student's mini research assignment in conducting research to school.

Based on the description above, it is clear that the importance of the mini research handbook in the subject of student development at Medan State University. To be able to achieve these expectations, this research is entitled "Developing A Mini Research Guide Book on Student Development Subject for First Semester Education Students of Medan State University"

\section{Mini Research Guide Book}

Practice Handbook is often referred to as manuals, guidebooks, and handbooks. The guidebook is a book that contains information and instruction. That is a guide for the reader to know something completely. The practicum guide book is an independent learning book which includes a series of practicum activities planned systematically to help students to be able to carry out group counseling practices well so that the goals of group counseling can be achieved. Where the contents of the practicum guidebook are in the form of instructions and descriptions for practicum.

Guidebook is one form of teaching material that is packaged in a complete and systematic manner that includes a set of learning experiences as a learning tool that is independent so that students can learn independently. This opinion is in line with the Ministry of National Education [1] that explains that the guidebook is a set of teaching materials that are presented systematically so that students can learn with or without a teacher.

Widodo \& Jasmadi [2] mention several steps in the preparation of the guidebook are as follows: (1) determine competency standards, (2) carry out a needs analysis of the learning guidebook, (3) drafting a guidebook, (4) do trial of draft manuals, (5) validation, (6) revision and production. By taking into account the steps in preparing the guidebook, making the development process of the guidebook will be structured.

The aspects and indicators that are used to evaluate the lesson guide book so that knowing a good guidebook is to consider assessment aspects such as (1) aspects of feasibility of content, (2) linguistic aspects, (3) aspects of presentation, and (4) aspects of graphics. From these aspects it can be used as a reference to make an instrument for assessing the feasibility of a guidebook (National Education Department).

The guidebook made is a book provided to facilitate prospective teacher students in carrying out Mini Research, so a Worksheet was prepared, so that what students observed as prospective teachers could be documented. Through learning material in the form of a Mini Research manual, students can learn easily get information related to the procedure or stages in completing a Mini Research assignment.

\section{Mini Research Tasks}

The mini research is a scientific paper written by students as an assignment given by lecturers in a course. The purpose of this mini research is to find out the thoughts or ideas of students about a particular problem. The theme raised in this paper is free. The written work can be in the form of research ideas, business ideas, and the like. With this mini research, it is expected that the relevant student can apply his creative ideas into a written form so that in the future he will be able to assist the student in conducting actual research. 
Adolescent Development Tasks

a. Physical Development

Damon said there are at least four mechanisms that are known to influence physical development, namely: factors looking for targets or self-stabilizing factors (self-stabilizing factor or self-stabilizing factor), speed of maturity, regulation of feedback (feedback regulation) and body mass.

\section{b. Cognitive Development}

The characteristic of cognitive development in childhood is concrete operational thought. At this stage, operation carried out by changing actions mentally, showing conservation skills, and reasoning logically replaces intuitive reasoning, but only in concrete, non-abstract situations, with the help of children's cognitive educators can be developed.

\section{c. Language Development}

Based on the results of the research, developmental psychologists define language development as an individual's ability to master the vocabulary, speech, grammatical, and pronunciation ethics in a certain period in accordance with the development of chronological age. Comparison between chronological age and individual language ability shows the individual's language development.

\section{d. Emotional Development}

Chaplin in the Dictionary of Psychology defines emotion as an aroused state of an organism including conscious changes that are profound in nature from behavioral change. Chaplin distinguishes emotions from feelings, and he defines feelings as feelings of conscious experience that are activated both by external stimulants and by various physical states.

\section{e. Development of Special Talents}

Talent implies that Bawan's ability is a potential (potential ability) that still needs further development and training. Because of its potential or latent nature, talent is a potential that still requires serious and systematic development and training efforts to be realized.

\section{f. Social Development}

Sunarto and Hartono state that social relations (socialization) are relationships between people who need each other. Social relationships start from simple and limited levels, which are based on simple needs. As adults mature and age, human needs become complex and thus the level of social relations also develops complexly so that it needs to be stimulated by educated educators.

\section{g. Moral Development}

Moral development (moral development) includes the development of thoughts, feelings, and behavior according to rules or habits regarding things that should be done when someone interacts with others (Hurlock). Moral development is very influential on the environment so that during these children the parents and the environment are very influential on the child's moral development, positive morals will have a good impact on the future, and vice versa if the child from childhood only accepts negative moral then the child will develop not in accordance with that his parents expected.

\section{h. Development of Self-Concept}

Self-concept is defined by Atwater states that in the overall self-concept of self-image, which includes one's perception of self, feelings, beliefs, and values related to him. Next, identify the self-concept of three forms, namely the first body image, awareness about the 
body, namely how a person sees himself; the second ideal self, how one's ideals and expectations about him; and third, social self, namely how other people see themselves.

\section{i. Personality Development}

Adolescence is a time of identity development that is a central issue in adolescents that provides a basis for adulthood. It can also be said to be a central aspect of a healthy personality that reflects self-awareness, the ability to identify other people, and to learn other goals so that they can participate in their culture. If adolescents fail to integrate aspects and choices or feel unable to choose, they will experience confusion (confusion) and need the help of educators.

\section{Research Method}

The research carried out is the type of research and development (Research and Development or R \& D). Development research steps followed Borg and Gall [3] in Sugiyono [4] said that the model of development has the following steps:

1. Research and information gathering

a. Requirement analysis

At the initial research stage, data collection was carried out through observation and interviews with lecturers in the subject of student development on March 20, 2019. Based on the interview results obtained information that there is no guidebook for mini research assignments that can be used as learning media. In addition, the results of the needs analysis for students on April 5, 2019 about the need for developing a mini research assignment manual for Unimed students showed a very high category of $95 \%$. Based on the results of the needs analysis conducted it can be concluded that the development of a mini research assignment handbook for the subject of Student Development in accordance with the needs in the Unimed educational study program.

At this stage, various kinds of literature studies are carried out by studying the relevant literature and in accordance with the variables of the research to be developed, namely the literature relating to Student Development[8]. Based on the literature on the discussion of literature review, related material is:

1) Mini Research Instrument of Physical Development

2) Mini Research Instrument of Cognitive Development

3) Mini Research Instrument of Emotional Development

4) Mini Research Instrument of Language Development

5) Mini Research Instrument of Special Talent Development

6) Mini Research Instrument of Social Development

7) Mini Research Instrument of Moral Development

8) Mini Research Instrument of Adolescent Development Tasks

9) Mini Research Instrument of Self-Concept Development

10) Mini Research Instrument of Self Adjustment Development

11) Mini Research Instrument of Personality Development 


\section{b. Planning}

The media developed in this study is the development of media in the form of a guidebook. The guidebook is one of the media that contains elements of images, text and independent assignments[5]. This is intended to generate positive enthusiasm from students. Handbook material contains a mini assignment research guide for Student Development subjects.

2. Initial product development is making and compiling material about the Mini Research Tasks of Student Development Subjects, then made into a guidebook (draft 1).

3. Initial field trials are testing the quality of the guidebooks. This trial was conducted to measure the feasibility of the manual through the validation of material experts and media experts.

4. Revised preliminary field trials of the quality of the guidebooks that have been tested with material experts, media experts, and BK service experts and then revised according to what was suggested as a guidebook (draft II).

5. Main field trials, testing a guidebook on a small group of 50 student subjects using a sample selection technique that is random sampling.

6. Revision of the main field trial, if there is a result of the content of the manual book that is unsatisfactory or the material that is not appropriate in the main field test then the manual is revised again in accordance with the suggestions and criticisms from small groups (Draft III).

7. Operational field trials, trying a guidebook to a large group of 150 students on trial subjects.

8. The final product, based on the results of evaluations from operational field trials, has become an appropriate final product to be implemented.

9. Product dissemination and implementation, disseminating the manuals that have been made and disseminating and disseminating them, which can be done in collaboration with publishers to publish the products that have been made.

The product development that will be carried out in this research reaches the tenth stage, which is the Dissemination and Implementation of the product, disseminating the manuals that have been made and disseminating and disseminating them [6,7].

\section{Data Collection Techniques and Instruments}

Data collection techniques in this study used a questionnaire to assess the feasibility of the guidebook through material experts and media experts[8]. Data collection techniques are the method chosen and used in research activities so that research can run systematically. The data collection in this study used questionnaire data collection or questionnaire of the feasibility of the guidebook through expert validation and the effectiveness of the guidebook questionnaire given to students in limited product trials [9].

The development procedure in this study can be presented in this figure below 


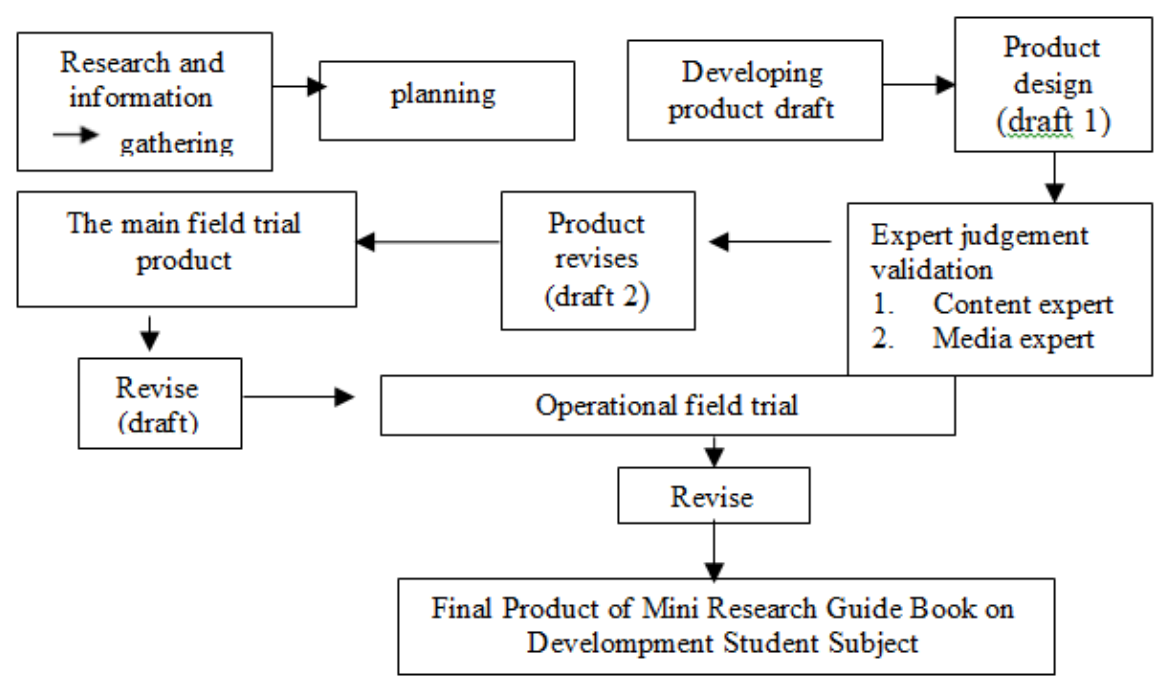

Fig 1. Development Research Steps

\section{Data analysis technique}

The data analysis technique used in the research development of this guidebook is to use quantitative data analysis. Quantitative data analysis was obtained by descriptive quantitative analysis, namely analyzing quantitative data obtained from expert validation and limited field trials and trials of Suharsimi's operational field [10]. In this study a questionnaire was used with the following formula:

Value $=\underline{\text { Obtained Score }} \times 100$

Total score

\section{Results and Discussion}

The development of a mini research assignment manual for Unimed Education Semester I students has been completed. The process of completing this manual is carried out in stages in order to produce communicative learning media products that are suitable for use. The making of this guidebook product has gone through a series of expert validations and field trials on users, besides expert validation and field trials are intended to obtain data as revision material.

The process of making this manual has been revised gradually in accordance with the advice given by material experts, media experts and data obtained from field trials at each stage. After the main field trials and operational field trials and data analysis at each stage of the trial, it can be concluded that this manual has become an excellent final product to be used as a learning medium that can be used by Unimed students.

The excellent results obtained by the service media are based on the results of the validation of media experts, material experts, as well as the process of main field trials and operational field trials. At the media expert validation stage, a score of 78 was obtained so that the value of 97.5 was in "Very Good" category. At the material validation stage the score was 93 so that the value of 93 was in "Very Good" category. At the main field trial stage, Based on the 
results of the questionnaire obtained a total score of 4759 so that the value of 95.18 with Very Good category. At the operational field trial stage, the total score of 13768 was obtained so that the value of 91.78 was in Very Good category.

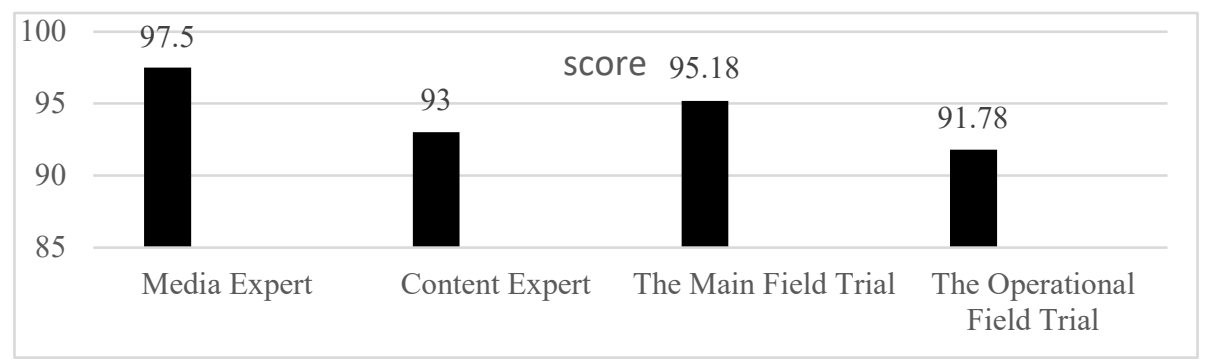

Fig 2. Score chart of expert test assessments and field trial

The Effectiveness of the Mini Research Guide Book for Developmental Student Subject

The results of students 'level of understanding of the mini research assignment handbook for students' developmental subjects were carried out after an operational field test. The assessment was carried out using a questionnaire level of effectiveness of the mini research assignment handbook for Student Development Subjects held on Wednesday, August 20, 2019 in the first semester of Unimed Education with a total of 30 students. the results of the assessment of the level of understanding of students known number of scores obtained 1240 so that the value of 93 with the category Very Good.

\section{Conclusion}

The results of this research and development are mini research assignment manuals for students' development for Unimed Education's first semester students. This manual contains cover, preface, table of contents, how to use, introduction, and material that each has their own instruments, cover, and bibliography. Mini assignment research manual for student development course for first semester students in Education Unimed from the results of the assessment by experts has been declared fit for use as a learning medium, and from the results of trials by users after going through initial field trials, main field trials, and operational field tests included in the very good category.

\section{References}

[1] Republik Indonesia. Panduan Penyusunan Capaian Pembelajaran Lulusan Program Studi. Kementerian Pendidikan dan Kebudayaan (2014).

[2] Widodo, C. S., \& Jasmadi. Panduan Menyusun Bahan Ajar Berbasis Kompetensi. Jakarta: PT. Elex Media Komputindo (2008).

[3] Gall, J. P., \& Borg, W. R. Educational Research an Introduction; Third Edition. USA: Pearson Education (1983). 
[4] Sugiyono. Metode Penelitian Pendidikan Pendekatan Kuantitatif, Kualitatif dan R\&D. Bandung:Alfabeta (2013).

[5] Hurlock Elizabet B. Psikologi Perkembangan Suatu Pendekatan Sepanjang Rentan Kehidupan. Jakarta: Erlangga (1993).

[6] Rahmulyani. dkk. Dimensi Perkembangan Remaja. Medan: Publisher (2018).

[7] Rahmulyani. dkk. Perkembangan Peserta Didik. Medan: Unimed Press (2018).

[8] Syah, Muhibbin. Psikologi Belajar. Jakarta: Rajawali Pers (2011).

[9] Suharsimi, Arikunto. Prosedur Penelitian. Jakarta: PT RinekaCipta (2010).

[10] Suharsimi, Arikunto. Prosedur Penelitian. Jakarta: PT RinekaCipta (2010). 